Андріянова Н. М.

Центр воєнно-стратегічних досліджень Національного університету оборони України імені Івана Черняховського, Київ

\title{
Трансформація діяльності НАТО після закінчення “холодної війни"
}

Резюме. У статті проаналізовано мету, етапи та напрями трансформації НАТО в період з 90-х рр. XX ст. та по сьогодні в умовах трансформації геополітичного простору Свропейського континенту. Метою перетворень є здатність Альянсу відповідати на загрози у сфері безпеки та забезпечення ефективного виконання ним поставлених завдань. Трансформація НАТО є однією з найважливіших умов реалізації завдань Альянсу у галузі безпеки, є тривалим і безперервним процесом та охоплює низку сфер: політичну, економічну, військову, організаційну, освітню та морально-психологічну.

Ключові слова: трансформація; стратегія; збройні сили; безпека; НАТО; саміт.

Постановка проблеми. Проблема становлення механізмів міжнародної безпеки в Свропі наприкінці 90-х рр. XX ст. та початку XXI ст. найтіснішим чином пов'язана 3 трансформацією

Організації Північноатлантичного договору (НАТО) та збройних сил країн-членів Альянсу. Глибоке реформування НАТО і посилення його ролі у розв'язанні низки принципових проблем розвитку Свропи перетворили Альянс не тільки в ключову ланку в ланцюзі інститутів регіональної безпеки, а й в один 3 вирішальних чинників становлення системи колективної безпеки на Європейському континенті в цілому [1, с. 12-13].

Тема трансформації Альянсу грунтується на широкій джерельній базі. На формування позиції автора статті істотний вплив мали наукові праці вітчизняних дослідників i практиків. У методологічному плані для розв'язання порушеної проблеми особливий інтерес представляють роботи В. Горбуліна, I. Храбана, М. Будакова, О. Полторацького, Т. Брежневої, С. Ліпкевича, А. Калашнікова, В. Корендовича та ін.

Актуальність досліджень 3 цієї тематики зумовлено потребами проведення реформи Збройних Сил України в умовах агресії РФ проти України [2], зовнішнього політичного курсу України на євроатлантичну інтеграцію [3] та співробітництва 3 країнамичленами НАТО.

Метою статті $\epsilon$ проведення аналізу етапів, мети та напрямів трансформації НАТО в умовах трансформації геополітичного простору Європейського континенту, крізь призму трьох останніх Стратегічних концепцій НАТО, після закінчення "холодної війни".
Виклад основного матеріалу. Організація Північноатлантичного договору $\epsilon$ військовополітичним союзом, створеним для захисту країн Євроатлантичного регіону, насамперед від зовнішніх загроз. Метою НАTO $\epsilon$ колективний захист його країн-членів [4]. Щоб забезпечити досягнення цієї мети, Альянс застосовує засоби політичного впливу або вдається до військових заходів залежно від характеру загрози безпеці країни-члена Альянсу. Об'єктивна потреба бути здатним протистояти сучасним новим загрозам викликала необхідність змін у функціонуванні Альянсу, що знайшло своє відображення у новому i розповсюдженому понятті “трансформація".

Трансформація - це процес, в якому поєднується досвід, інноваційне мислення, удосконалення концепцій, результати досліджень та технології, експеримент, навчання та освіта 3 метою покращення рівня можливостей. Це модель, яка має перспективу на майбутне i поєднує у собі поточні та майбутні зміни. Без таких змін i без удосконалення потенціалу НАТО може легко стати недосконалою структурою, яка не зможе справлятися 3 реаліями військових потреб у ХХІ столітті [5, с. 342-345].

В історії НАТО практично не було періоду, коли б Альянс не знаходився у процесі пошуку нових способів організації і функціонування. Об'єктивними передумовами завжди були зміни в міжнародній ситуації, про що свідчить еволюція стратегічних концепцій Альянсу (рис. 1), суб' єктивними - внутрішній розвиток й відносини між країнами-членами Альянсу [6, c. 144-150].

Трансформація НАТО визначає сутність сучасного Альянсу. Метою перетворень $\epsilon$ можливість відповідності Альянсу ситуації у 
сфері безпеки та забезпечення ефективного виконання ним тих завдань, які він взяв на себе. Відповідно до прийнятих рішень трансформація охоплює низку сфер, які взаємопов'язані та взаємозалежні: політичну - розширення зони відповідальності та союзників; військову - нові погляди на ведення бойових дій; організаційну - планування та нова організація забезпечення військ; структурну - нова військова структура; освітня - нові методи та підходи в підготовці військовослужбовців; морально-психологічну - зміни у свідомості та поведінки людей. Умовно, в хронологічних рамках дослідження, можна визначити три етапи трансформації Альянсу: перший - від початку 90-х років XX ст. до 11 вересня 2001 року; другий - 311 вересня 2001 року до початку агресії РФ проти України; третій - 3 березня 2014 року по сьогодні. На першому етапі, імператив трансформації фактично постав перед НАТО 3 моменту закінчення "холодної війни" ліквідації Організації Варшавського договору (ОВД), розпаду СРСР у 1991 р., суспільнополітичних змін та реформ політичних i економічних систем, які відбулися в колишніх соціалістичних країнах Центральної Європи зумовили необхідність перегляду Альянсом своїх завдань і проведення трансформаційних заходів. Тому потрібні були широкомасштабні внутрішні реформи для пристосування до нових геополітичних умов та вирішення нових завдань, таких як урегулювання криз, миротворча діяльність i операції 3 підтримання миру та безпеки (ОПМБ), а також підтримання військових структур 3 погляду їхньої здатності виконувати традиційну роль у сфері оборони. Зважаючи на нові виклики у галузі безпеки, НАТО ще 3 початку 1990-х років відповідальністю за колективну оборону до організації, яка стала центром розвитку партнерських відносин між країнами, які тісно співпрацюють із питань безпеки в різних напрямах і сферах.

Доля НАТО була вирішена на лондонській зустрічі 1990 року, де глави держав і урядів країн Альянсу оприлюднили Лондонську декларацію про трансформацію Північноатлантичного Альянсу. У листопаді 1991 року на Римському саміті, була оприлюднена перша відкрита Стратегічна концепція НАТО [7], у якій відобразились зміни що відбулись у світі після закінчення “холодної війни”. Основою цієї концепції, після стратегії “гнучкого реагування", стала стратегія "управління кризами" або "кризового реагування", а регіональні конфлікти були включені у список “викликів і ризиків", які замінили колишню "загрозу зі сходу”, що дало змогу НАТО брати участь в ОПМБ (див. рис. 1). Крім того, у концепції було визначено три основоположні принципи подальшого функціонування Альянсу:

принцип колективної оборони;

принцип діалогу;

принцип співробітництва.

Після тривалих дискусій про структуру та функції Альянсу в нових геополітичних умовах було прийнято рішення про головні напрями його трансформації відповідно до завдань XXI сторіччя [8, с. 53-54]. У стислому вигляді ці трансформаційні напрями полягали у тому, щоб:

пристосувати Альянс до виконання нових завдань, враховуючи нові виклики безпеці;

розширювати можливості для прийому нових членів;

зміцнити партнерство 3 країнами Європи та постсоціалістичними країнами.

При цьому головну увагу було зосереджено на посиленні політичної ролі Альянсу та його внеску разом 3 іншими міжнародними організаціями у справу збереження безпеки і стабільності, від яких залежіть майбутнє Європи.

Наслідком ухвалення нової Стратегічної концепції НАТО 1991 року стало:

1. Створення в грудні $1991 \mathrm{p}$. Ради північноатлантичного співробітництва (РПАС), до якої можуть увійти не лише країни НАТО, але й країни, які не є іiї членами [9, с. 42-43]. 30 травня 1997 р. у м. Сінтра (Португалія) міністри держав Альянсу та країн-партнерів ухвалили рішення про створення Ради євроатлантичного партнерства (РСАП), яка прийшла на зміну Раді північноатлантичної співпраці (РПАС) [9, с. 19-20].

2. На січневому 1994 року Брюссельському саміті НАТО запровадила нову ініціативу, офіційно було проголошено програму “Партнерство заради миру” (ПЗМ) [9, с. 69-71].

3. 3 грудня 1994 року НАТО заявила, щоправда опосередковано, про можливість розширення на Схід. У вересні 1995 було розроблено i опубліковано документ “Дослідження про розширення НАТО", а у грудні 1995 року цей документ було схвалено на черговому Брюссельському саміті як “документ практичної дії” [9, с. 63-64]. 


\section{Етапи розвитку і стратегічні концепції НАТО}

Лісабонський саміт, листопад 2010 р. Стратегічна концепція 2010p.

Головна риса концепції 2010 р.:

закріплення військової присутності альянсу в Центрально-

Азійському регіоні;

гнучка політика по відношенню до Росії;

нові принципи застосування сили в так званих "умовах відсутності війни"

\begin{tabular}{l|l} 
“НАТО 2020: \\
$\begin{array}{c}\text { впевненість в } \\
\text { безпеці; } \\
\text { динамічні } \\
\text { підходи" }\end{array}$
\end{tabular}

Вашингтонський саміт, квітень 1999 р. Стратегічна концепція 1999р.

Закріплення

лідируючої ролі

Альянсу у

побудові нової

архітектури

безпеки в

Європі і

Північної

Америки

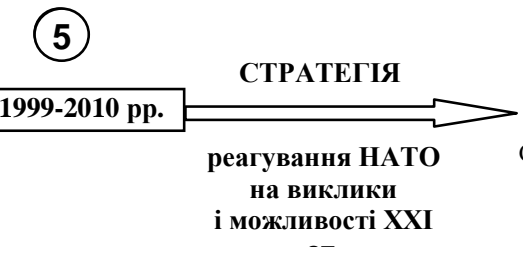

Головна риса конщепції 1999 р.:

збереження трансатлантичного зв'язку і ефективної обороноздатності; розвиток ЄСБО в межах Альянсу;

запобігання конфліктам і врегулювання криз;

партнерство, співпраця і діалог (РСАП, ПЗМ, РФ, Україна,

Середземноморський діалог);

розширення - відкритість Альянсу для вступу нових членів; контроль за озброєннями, роззброєння і непоширення ЗМЗ

\section{Конкретизація концепції 1999 р.:}

Празький Саміт НАТО (листопад 2002 р.);

Стамбульський Саміт НАТО (червень 2004 р.);

Ризький Саміт НАТО (листопад 2006 р.)

\section{Римський саміт, листопад 1991р. Стратегічна концепція 1991р}

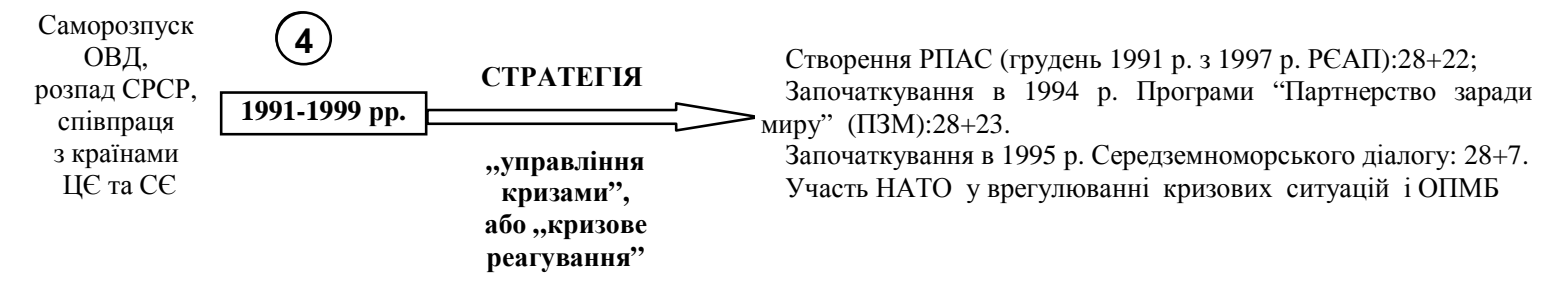

Січень 1968 р. Стратегічна концепція щодо захисту території

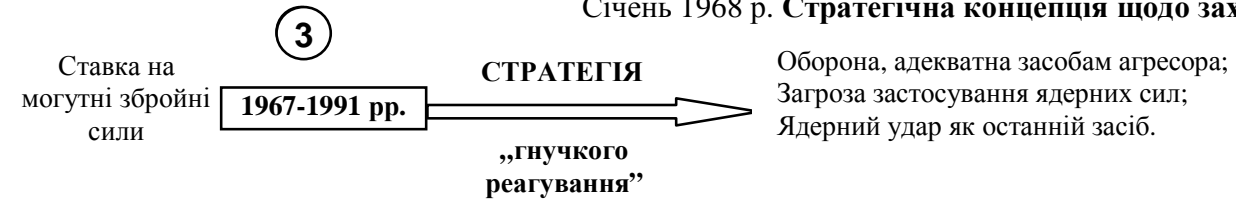

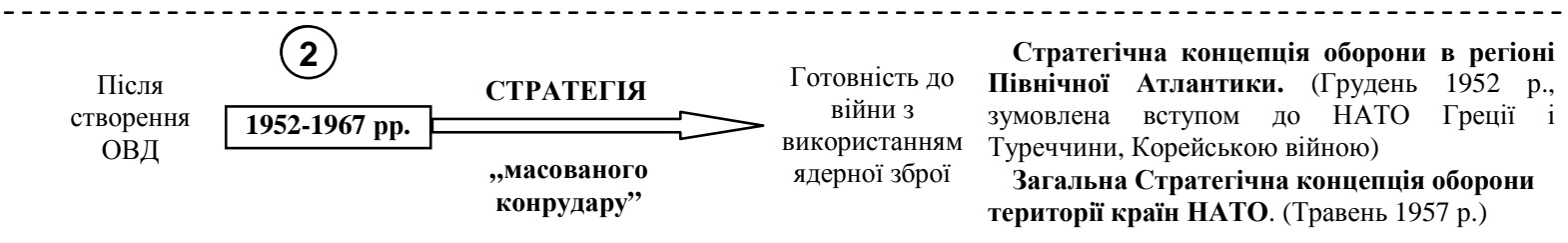

Після
$\begin{gathered}\text { створення } \\ \text { НАТО }\end{gathered}$

Рис. 1. Етапи розвитку і стратегічні концепції НАТО 
4. У 1995 році була запропонована Ініціатива Середземноморського діалогу. Було названо 6 країн як потенційних партнерів НАTO: Ізраїль та 5 арабських країн Мавританія, Марокко, Туніс, Сгипет, Йорданія [9, с. 94-95].

5. У липня 1997 року відбувся Мадридський саміт НАТО, де було заявлено про три країни, які будуть прийняті до НАТО: Чехія, Польща та Угорщина [9, с. 21]. У грудні 1997 року ці три країни підписали офіційні протоколи про приєднання до НАТО. Урочисте прийняття відбулося у квітні 1999 року у Вашингтоні, де 50 років тому було підписано Північноатлантичний договір. Це стало першим фактор розширення НАТО за рахунок колишніх “противників" [9, с. 1718].

6. Наприкінці 1993 року була ініційована, а на Брюссельському саміті НАТО прийнята концепція створення Багатонаціональних об'єднаних оперативнотактичних сил (БООТС) [9, с. 264-265].

7. Сформована концепція миротворчої діяльності НАТО дала змогу отримати вагомий результат діяльності НАТО - успішні операції з підтримання та встановлення миру не лише в Європі, а й у країнах Азії та Африки, що свідчить про значне розширення географічних рамок проведення місій за межами зони відповідальності Альянсом [10].

Нові глобальні загрози безпеці, які виникли на рубежі XX i XXI ст. зумовили необхідність вироблення нової стратегічної концепції реагування НАТО на виклики i можливості XXI ст., переходом від Стратегічної концепції НАТО 1991 року до Нової стратегічної концепції Альянсу, прийнятої 24 квітня 1999 року на Вашингтонському саміті НАTO [11], яка вказувала шлях майбутнього політичного й військового розвитку організації (див. рис. 1).

Головна ідея нової стратегічної концепції 1999 року - вільне розширення HATO. У концепції наголошувалось на необхідності співробітництва із країнами колишнього Варшавського договору та державами, які утворилися після розпаду СРCP [11, c. 11].

Основною і незмінною метою Альянсу залишається захист свободи і безпеки всіх членів Альянсу за допомогою політичних i військових заходів. Для досягнення своєї мети НАТО передбачає виконання низки фундаментальних завдань у сфері безпеки:

гарантувати розвиток демократичних інститутів та мирне вирішення конфліктів; виконувати функцію головного трансатлантичного форуму, для консультацій між членами Альянсу;

стримувати i захищати від будь-якої загрози держав-членів;

розвивати широкомасштабні програми партнерства [11, с. 13].

Узагальнюючи можна виділити такі напрями першого етапу трансформації Альянсу:

пристосування Альянсу до виконання нових завдань, враховуючи нові виклики безпеці; HATO;

скорочення збройних сил країн-членів

реорганізація командної структури НАТО (кількість штабів: до 1990 р. - 65; 31991 р. - 20; з 1999 p. - 11);

участь НАТО у врегулюванні кризових ситуацій і ОПМБ;

розширювання можливостей для прийому нових членів (політика відкритих дверей);

співпраця НАТО і ЄС в галузі безпеки;

зміщення акцентів діяльності 3 військових на політичні;

партнерство заради безпеки (створення РПАС у грудені 1991 р. з 1997 р. РЄАП: 28+22; започаткування 3 січня 1994 p. програми "Партнерство заради миру" (ПЗМ): 28+23; в $1995 \mathrm{p}$ запропонована Ініціатива Середземноморського діалогу: 28+7);

особливе партнерство 3 Росією i Україною;

розширення цивільного виміру діяльності (у сфері планування та реагування на надзвичайні ситуації, наукова програма "Безпека через науку", Цільові та Трастові фонди (ТФ) ПЗМ).

Історичне рішення НАТО щодо застосування статті 5 Вашингтонського договору та надання допомоги США після терористичних нападів 11 вересня 2001 року, започаткувало другий етап трансформації НАТО, який характеризується продовженням трансформаційних процесів, започаткованих на першому етапі. Треба зазначити, що на сьогодні не існує єдиної Програми трансформації НАТО. На другому етапі трансформації НАТО іiі фактично складають рішення Самітів Альянсу, що відбулися у Празі (2002 р.), Стамбулі (2004 р.), Ризі (2006 р.) i низкою ініціатив щодо змісту та характеру діяльності організації [12]. Серед них:

програма, ініційована на Празькому саміті (2002 p.) колишнім Генеральним секретарем лордом Робертсоном, стосується 
військової та організаційної сфер, зосереджена на змінах у можливостях, місіях і структурах Альянсу;

Норфолкська програма, ініційована Генеральним секретарем Яапом де Хооп Схеффером у 2004 році у відповідь на “уроки Афганістану”, зосереджена на змінах в оборонному плануванні, генеруванні збройних сил i спільному фінансуванні, тобто в основному стосується військової сфери;

Мюнхенська програма, ініційована колишнім канцлером Німеччини Г. Шредером у 2005 році у відповідь на уроки “іракської кризи”, зосереджена на змінах ролі НАТО як засобу реальних трансатлантичних стратегічних консультацій і прийняття рішень, тобто пропонує початок трансформаційних змін у політичній сфері [13 с.78].

Відповідно до Празької програми, трансформація передбачає всеохоплюючу програму заходів: удосконалення потенціалів, створення сил швидкого реагування, реорганізацію командної структури Альянсу, розширення безпекового простору через прийняття нових членів та розвиток партнерських стосунків, поліпшення трансатлантичних і союзницьких відносин, які мають зробити НАТО спроможним для виконання всього спектру сучасних завдань у сфері безпеки [14].

Виконання Празьких зобов'язань щодо обороноздатності знайшло своє продовження на Стамбульському саміті у червні 2004 року [15]. На саміті були ухвалені Комплексні політичні настанови (Comprehensive Political Guidance), які забезпечують рамки та політичний напрям продовження трансформації НАТО, встановлюючи на наступні 10-15 років пріоритети 3 усіх аспектів військового потенціалу Альянсу, планування, підготовки та розвідки [8, с. 68-70].

У перше десятиліття XXI ст., склались певні передумови, що потребували перегляду стратегії Альянсу, серед них: поява нових загроз, таких як міжнародний тероризм i біологічна зброя, поширення балістичних ракет і ядерної зброї, кібернетичні напади i фундаментальні екологічні проблеми; кардинальні зміни у відносинах 3 Росією; потреба у військовій реформі та інші.

Саме тому в листопаді 2010 року під час саміту НАТО в Лісабоні, була представлена Нова Стратегічна концепція Альянсу "Активна участь, сучасна оборона" - чітка i рішуча заява про найважливіші завдання та принципи НАТО, ऑii цінності в мінливих умовах безпеки i стратегічні цілі
Північноатлантичного союзу на найближчі десять років [16] (див. рис. 1).

Нова Стратегічна концепція НАТО отримала розвиток на Чиказькому самміті. У декларації Чиказького самміту "Про оборонні можливості" серед важливих досягнень та завдань була запропонована ідея "розумної оборони" (Smart Defence) яка стала ядром нового підходу НАТО до оборонних можливостей [17].

Агресія РФ проти України відродила ризик міжнародних зіткнень і показала, що територіальна цілісність будь-якої країни перебуває під загрозою та започаткувала третій етап трансформації НАТО, який триває по теперішній час і характеризується переходом від “стратегії страхування" союзників у Свропі, до “стратегії стримування” агресії РФ.

Останні два роки, після саміту в Уельсі [18], у НАТО працювали над втіленням Плану дій щодо забезпечення готовності (Readiness Action Plan) i зміцненням сил стримування i оборони. Було втричі збільшено чисельність сил швидкого реагування - до 40 тисяч військових. Створена група надшвидкого реагування чисельністю 5 тисяч військових, яка протягом 48 годин може бути розгорнута у будь-якій точці Європи.

Альянс створив вісім нових малих штабквартир у східних країнах, завдання яких координувати пересування техніки, проведення навчань i накопичення необхідного обладнання.

Наступним важливим кроком у трансформації діяльності НАТО, в умовах нових загроз безпеці у Свропі, було проведення у липні 2016 року Варшавського саміту лідерів країн-членів Альянсу.

Головним результатом саміту НАТО у Варшаві стало публічне озвучення готовності Альянсу відповідати на виклик з боку Росії. В оприлюдненому комюніке за результатами Саміту, Росію, вперше після довгого часу, відкрито визнано країною, чиї “агресивні дії, включаючи провокаційні військові дії на кордонах НАТО та бажання досягати політичних цілей шляхом погроз та застосування сили, є джерелом нестабільності в регіоні, головним викликом Альянсу, що завдало шкоди системі Свроатлантичної безпеки" [19].

Альянс прийняв рішення щодо вжиття додаткових заходів по стримуванню агресивної політики Росії, зокрема:

посилено Сили реагування НАТО;

створено нові Об'єднані сили високого ступеню готовності до дій (Very High Readiness 
Joint Task Force, VJTF), що здатні до дій вже протягом 2-3 діб;

створено вісім багатонаціональних підрозділів інтеграції сил НАТО (NATO Force Integration Unit, NFIU), що мають забезпечити оперативне розгортання сил НАТО (Об'єднаних сил високого ступеню готовності до дій; та складових елементів сил відповіді HATO - NATO Response Forse elements, NRF);

вжиті необхідні заходи для підвищення здатності НАТО для посилення за рахунок нових проектів в області інфраструктури i підвищення гнучкості в швидкому переміщенні сил по території країн-членів Альянсу;

Північноатлантичний Альянс затвердив рішення про створення двох нових командних центрів в рамках адаптації структури НАТО до нових загроз:

перший командний центр (Joint Force command for the Atlantic) буде захищати морські комунікації між Свропою та Північною Америкою та пов'язану із цим критичну інфраструктуру;

другий командний центр (Support command) має забезпечити швидке пересування військ та техніки територією Європи;

розширено програму навчань НАТО;

посилено можливості 3 розширеного планування та прискореного прийняття рішень 3 метою забезпечення як військового, так і політичного реагування;

погоджено стратегію щодо ролі НАТО в боротьбі 3 гібридною війною, яка здійснюється в координації з СС.

Таким чином, проведений аналіз мети, етапів та напрямів трансформації НАТО дає змогу дійти таких висновків:

трансформація НАТО $є$ однією 3 найважливіших умов реалізації завдань Альянсу у галузі безпеки, основоположним 3 яких $є$ гарантування свободи та безпеки усіх його членів згідно 3 принципами Статуту $\mathrm{OOH}$, ii мета - зміцнити здатність Альянсу протидіяти існуючим та новим безпековим загрозам XXI-го століття, включаючи надання повністю підготовлених та здатних до розгортання сил, які можуть виконувати повний спектр військових операцій та місій на своїй території та поза іiі межами, по іiі периметру та на стратегічній відстані;

трансформація НАТО $є$ тривалим i безперервним процесом, оскільки у політичному, економічному, соціальному середовищі, а також у сфері безпеки постійно відбуваються зміни, які часто створюють для
Альянсу труднощі та вимагають прийняття складних рішень;

після закінчення “холодної війни”, можна визначити три етапи трансформації Альянсу: перший - від початку 90-х років XX ст. до 11 вересня 2001 року; другий - 311 вересня 2001 року до початку агресії РФ проти України; третій - 3 березня 2014 року по сьогодні;

основними напрямами трансформаційних процесів Альянсу в цілому $є$ реформування військових командних структур, військова та військово-політична трансформація.

Подальші дослідження необхідно зосередити на вивченні трансформації збройних сил країн-членів Альянсу як інструменту реалізації воєнної політики держави, для врахування під час реформування ЗС України, в умовах складної воєннополітичної обстановки на Сході України.

\section{СПИСОК ВИКОРИСТАНОЇ ЛІТЕРАТУРИ}

1. Партнерство заради безпеки: досвід країн НАТО та українська перспектива / За загальною ред. О. І. Соскіна. - К.: Вид-во "Інститут трансформації суспільства”, 2007. - 336 с. С. 12-13.

2. Закон України від 18 січня 2018 року, № 2268 VIII "Про особливості державної політики із забезпечення державного суверенітету України на тимчасово окупованих територіях у Донецькій та Луганській областях" м. Київ [Електронний ресурс] - Режим доступу: http://zakon2.rada.gov.ua/laws/show/2268-19.

3. Закон України від 1 липня 2010 року, № 2411-VI «Про засади внутрішньої i зовнішньої політики». м. Київ [Електронний ресурс] - Режим доступу: http://zakon2.rada.gov.ua/laws/show/241117.

4. Північноатлантичний договір Вашингтон, округ Колумбія, 4 квітня 1949 року [Електронний pecypc] - Режим доступу: http://zakon2.rada.gov.ua/ laws/show/950_008.

5. Андріянова Н. М. Трансформація НАТО: мета, етапи, напрями. “Гілея: науковий вісник”: Збірник наукових праць / Гол. Ред. В.М. Вашкевич. - К. "Видавництво "Гілея", 2017. - Випуск 124 (9) 354 c. $342-345$.

6. Міжнародні відносини i євроатлантична інтеграція України / За заг. ред. Л. С. Голопатюка - К.: HAOУ, 2005. C. 144-150.

7. The Alliance's New Strategic Concept. Agreed by the Heads of State and Government participating in the Meeting of the North Atlantic Council 07 Nov. 1991 08 Nov. 1991. [Електронний ресурс] - Режим доступу: www.nato.int/cps/uk/natohq/official_texts_ 23847.htm?selectedLocale $=$ en.

8. НАТО: історія, структура, діяльність, перспективи. Навчальний посібник - Луцьк: ВНУ ім. Л. Українки, 2008. - 258 с.

9. ДОВІДНИК НАТО. Office of Information and Press. NATO - 1110 Brussels. 2001. - 608 c. 
10. Андріянова Н. М.,

Тимошенко Р. I., Федянович Д. Л., Шпура М. І. Аналіз практики проведення операцій НАТО з підтримання миру і безпеки. Збірник наукових праць Центру воєнностратегічних досліджень Національного університету оборони України імені Івана Черняхівського. - К., 2017. - Випуск № 3(61). C.19-23.

11. Стратегічна концепція Альянсу. Затверджена главами держав і урядів 23-24 квітня 1999 р. Брюссель.: Відділ інформації та преси НАТО, 1999. - 19 c.

12. Україна і НАТО: використання міжнародного досвіду імплементації планів співробітництва: монографія - Дніпропетровськ: ДФ НІСД, 2006, c. 20.

13. Брежнєва Т. Використання досвіду країн другої “хвилі” розширення для визначення майбутньої ролі України в НАТО. Економічний часопис XXI. - K., 2005. - Випуск № 7-8. С. 78 - 89.

14. Prague Summit Declaration issued by the Heads of State and Government participating in the meeting of the North Atlantic Council / Prague Summit and NATO's Transformation. Brussels, 2003. [Електронний ресурс]: - Режим доступу: https://www.nato.int/cps/en/natohq/official_texts_19 552.htm

15. Istanbul Summit CommuniquéIssued by the Heads of State and Governmentparticipating in the meeting of the North Atlantic Council - 28 June 2004. [Електронний ресурс]: - Режим доступу: https://www.nato.int/docu/pr/2004/p04-096e.htm.

16. Strategic Concept for the Defence and Security of the Members of the North Atlantic Treaty Organisation adopted by Heads of State and Government in Lisbon - 19 November 2010. [Електронний ресурс]: - Режим доступу: http://www.nato.int/cps/en/natolive/official_texts_685 80.htm.

17. Summit Declaration on Defence Capabilities: Toward NATO Forces 2020 - Press Release (2012) 064 - Issued on 20 May. 2012. [Електронний pecypc] - Режим доступу: http://www. nato.int/ cps/en/ natolive/ official_ texts 87594.htm? mode=pressrelease.

18. Декларація Уельського саміту. Видана главами держав та урядів 5 вересня 2014 р. [Електронний ресурс]: https://www.nato.int/cps/uk/natohq/official_texts_112 964.htm?selectedLocale $=$ uk

19. Заява за результатами саміту у Варшаві. Оприлюднено главами держав та урядів, які беруть участь у засіданні Північноатлантичної ради у Варшаві 8-9 липня 2016 р. [Електронний ресурс]: https://www.nato.int/cps/uk/natohq/official_texts_133 169.htm.

Стаття надійшла до редакції 11.04.2018

\section{Андриянова Н. Н.}

Центр военно-стратегических исследований Национального университета обороны Украины имени Ивана Черняховского, Киев

\section{Трансформация деятельности НАТО после окончания “холодной войны”}

Резюме. В статье проанализированы цели, этапы и направления трансформации НАТО в период с 90-х гг. ХХ в. и по сегодняшнее время в условиях трансформации геополитического пространства Европейского континента. Целью преобразований является способность Альянса соответствовать ситуации в сфере безопасности и обеспечения эффективного выполнения им поставленных задач. Трансформация НАТО является одной из важнейших условий реализации задач Альянса в области безопасности, является длительным и непрерывным процессом и охватывает ряд сфер: политическую, военную, экономическую, организационную, образовательную и морально-психологическую.

Ключевые слова: трансформация; стратегия; вооруженные силы; безопасность; НАТО; саммит.

\section{N. Andriianova}

Center of military and strategic studies of the National Defence University of Ukraine named after Ivan Cherniakhovskyi, Kyiv

\section{Transformation of NATO after the Cold War}

Resume. The article analyzes the purpose, stages and directions of NATO's transformation from the 1990s to the twentieth century and to this day in the context of the transformation of the geopolitical space of the European continent. The goal of transformation is the ability of the Alliance to respond to the security situation and ensure that its tasks are effectively implemented. Transformation of NATO is one of the most important conditions for the Alliance's security tasks to be carried out, it is a long and continuous process and covers a number of areas: political, military, economic, organizational, educational, and moral-psychological.

Keywords: transformation; strategy; armed forces; security; NATO; summit. 